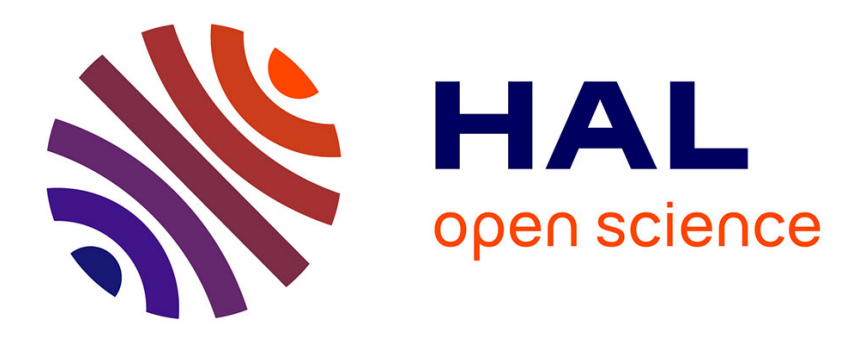

\title{
From self-organization to self-assembly: A New materialism?
}

\author{
Bernadette Bensaude-Vincent
}

\section{To cite this version:}

Bernadette Bensaude-Vincent. From self-organization to self-assembly: A New materialism? . History and Philosophy of the Life Sciences, 2016, 38 (3), pp.1-13. hal-01494485

\section{HAL Id: hal-01494485 \\ https://hal-paris1.archives-ouvertes.fr/hal-01494485}

Submitted on 23 Mar 2017

HAL is a multi-disciplinary open access archive for the deposit and dissemination of scientific research documents, whether they are published or not. The documents may come from teaching and research institutions in France or abroad, or from public or private research centers.
L'archive ouverte pluridisciplinaire HAL, est destinée au dépôt et à la diffusion de documents scientifiques de niveau recherche, publiés ou non, émanant des établissements d'enseignement et de recherche français ou étrangers, des laboratoires publics ou privés. 


\title{
From self-organization to self-assembly: A New materialism?
}

\author{
Bernadette Bensaude Vincent
}

\section{Introduction}

Over the past decades, self-assembly has revived the fascination for spontaneous activities in matter. How molecular units assemble to form an organized structure or pattern without intervention of an outside source is a puzzling process that chemists and physical-chemists intensively scrutinize. To what extent did this new research field transform the relation between physics, chemistry and biology? Is it a new episode of the longstanding fight between reductionism and vitalism?

Since self-organization has long been considered as a distinctive feature of living organisms, one could think that the shift of attention from self-organization toward self-assembly is one of the outcomes of the molecularisation of life, due to decades of intense research in molecular genetics and genomics. Given the technological connotation of the term assembly (which connotes an assembly line) one could presume that the focus on self-assembly marks the triumph of the mechanistic view of life over the anti-reductionnist traditions. Is it the symptom that the enigmatic spontaneity attributed to living cells has been reduced to the mechanical assembly of molecular building blocks?

It would not be the first time that chemists challenge the mystery of vital organization. Since early-modern alchemy, many chemists have claimed that they could reproduce life in a testtube. A major episode in this long tradition was Friedrich Wölher's synthesis of urea in 1828 , which allegedly destroyed the metaphysical belief in the existence of a vital force. It is a legend forged by nineteenth-century chemists who cared to demonstrate that life was merely a set of physico-chemical phenomena (Brooke 1968, Ramberg 2000). The metaphysical challenge was part of Marcellin Berthelot's grandiose dream of synthesizing all the compounds made by living organisms, using only elements and the range of molecular forces (Berthelot 1860). Berthelot boasted that starting with the four basic elements-carbon, hydrogen, oxygen, and nitrogen - and proceeding systematically from the most simple to the most complex compounds, chemists would dissipate the mystery of life. It was not too difficult for physiologists such as Claude Bernard, to retort to arrogant chemists that synthesizing a product from its elementary principles did not mean getting the properties of 
living beings (Bernard, 1865). He also emphasized that the synthetic process used by chemists in their laboratories was very different from those created by organisms. (Bernard 1866)

It is thus tempting to adopt the master narrative of the gradual triumph of science over metaphysics featuring the nineteenth-century reduction of biological products to chemical elements as a first conquest followed by the emulation of biological processes such as selforganization and self-assembly in the twentieth century. One can still find this sort of claims in recent publications. For instance an editorial in the journal Nature was headlined: "Synthetic biology provides a welcome antidote to chronic vitalism" (Nature, June 28, 2007) Synthetic biology is said to demonstrate that "life is a molecular process lacking moral threshold at the level of the cell." It thus challenges religious dogma about life and the "popular belief" that "life is something that appears when a clear threshold is crossed."

This essay discourages such positivistic claims. Considering the context of research on selfassembly I argue that the shift of attention from self-organization to self-assembly has no antivitalistic implications. Self-assembly was first and foremost investigated in an engineering context as a strategy for manufacturing without human intervention and did not raise new perspectives on the emergence of vital organization itself. However the emergence of selfassembly as a field of research has metaphysical implications.

The paper first describes the emergence of self-assembly as a research field in the context of materials sciences and nanotechnology. The second section outlines the metaphysical implications and will emphasize a sharp contrast between the ontology underlying the chemists' practices of self-assembly and the practices developed by synthetic biologists. Finally, the third section ventures some reflections on the kind of design involved in selfassembly practices.

\section{How self-assembly became a booming research field}

The term 'self-assembly' has been coined in an academic context, which significantly differed from the milieu where self-organization became a fashionable research topic in the twentieth century. To make a long story short, self-organization became a central concept in three different research communities (Stengers 1985). First, in the 1940s embryologists promoted self-organization in response to failed attempts at identifying a specific chemical substance that would induce the process of organization in early embryos (Feltz et al. 2006). Second, in the 1950s cybernetics prompted a redefinition of self-organization in the terms of Claude Shannon's theory of information. For John von Foester, self-organization meant order from noise with a decrease of relative entropy, and an increase of redundancy within the system (von Foerster 1960). The French biologist and philosopher Henri Atlan (1972) retained this definition while suggesting that it was complexity from noise, a process requiring a hierarchical multilevel system and initial redundancy. Third, Belgian physical-chemist Ilia Prigogine redefined the concept in thermodynamic terms on the basis of his investigation of 
dissipative structures (Nicolis and Prigogine 1977). Self-organization then referred to the evolution of an open system toward steady-states and this dynamic notion of self-organization concept has been extensively applied to a variety of domains ranging from biology to psychology and neurosciences, to economy.

In stark contrast, the phrase 'self-assembly' appeared in a more specific domain related to materials engineering. It was first used in the $1960 \mathrm{~s}$ by materials scientists who were struggling to design high-performance materials with unprecedented combinations of properties for space and military applications. This goal was achieved through the design of composite multifunctional structures. Ironically this new approach, known as "materials by design" because materials are not extracted from nature but individually built up for a specific set of functions, drew the attention of materials scientists to nature. They came to realize that biological structures - wood, skin, bones... - offered many examples of multifunctional composite materials. Stephen Mann - a natural scientist who entered the field of materials science - wrote: "We can be encouraged by the knowledge that a set of solutions have been worked out in the biological domain". (Mann et al. 1989, p. 35).

Materials scientists were especially interested in biomineralization where complex structures are assembled thanks to templates which bring together the components in the right position. In marine shells the inorganic component - calcium carbonate - nucleates and grows under the control of an organic matrix. While chemists and marine biologists joined their effort to explore mineralization processes, they realized that self-assembly is ubiquitous in the natural world and can be achieved through various methods (Ball 2002). One of the most elegant method is inspired by the phospholipids with hydrophobic and hydrophilic ends which form a stable structure when placed in aqueous solution. This method inspired by cell membranes relies on a process leading to equilibrium state through minimization of free energy. This arrangement has been literally mimicked to make synthetic liposomes employed as vehicles for drug delivery. The key to perform such structures is to control the kinetics of reactions. Performing chemical reactions under quasi-physiological conditions, with biodegradable and renewable by-products and with an economy similar to that of nature, is the agenda of a new style of chemistry, named "chimie douce" (soft chemistry) by Jacques Livage in 1977. In order to obtain materials whose structures and textures are determined by local energy minima rather than one global energy minimum, soft chemistry works in open reactor at ambient temperature and makes extensive uses of sol-gel route and molecular precursors.

Achieving molecular recognition is another favourite method. Emil Fisher's idea of the 'lock and key mechanism' which allows enzymes to click on a substrate has been extended to other molecules in supra molecular chemistry. This new branch of chemistry created by Jean-Marie Lehn in 1978 is clearly aimed at designing chemical processes that mimic the coding of biological processes. Its objective is to reproduce the selectivity of the interaction between receptors and substrates in biology, with the help of hydrogen bonds and stereochemistry. Thanks to molecular recognition the building blocks self-assemble to form supramolecular structures, and even materials. Selective and efficient assembly can be obtained not only with the help of hydrogen-bonding, but also with donor-acceptor interactions, or metal-ion 
coordination. According to Lehn, "it is one of the major chemist's motivation to see that biology successfully made highly complex properties on a molecular basis." (Lehn 2003) As important as molecular recognition is the role of catalysts in the environment, which trigger or alter the reactivity of the binding sites.

While developing a wide spectrum of biomimetic strategies chemists have gradually outlined the conditions for designing structure bottom-up, through self-assembly (Whitesides Boncheva 2005). First, the components must be able to move and interact; second, their interactions should be reversible in order for the components to explore a wide range of potentials for assembly; third, nevertheless in order to prevent the formation of defects the number of possible assemblies must be limited by the use of compartments or templates generating geometrical constraints. Harvard chemist George Whitesides insisted that selfassembly operates at all length-scales and opened up a fascinating perspective of design without human intervention:

Our world is populated with machines, non living entities assembled by human beings from components that humankind has made.... In the $21^{\text {st }}$ century, scientists will introduce a manufacturing strategy based on machines and materials that virtually make themselves (Whitesides 1995).

The perspective of self-made machines becomes crucial for engineering at the molecular scale, where human hands and tools cannot operate. Therefore self-assembly became the holy grail of nanotechnology. In the 1990s and 2000s ten percent of all nanotechnology publications were dealing with self-assembly (Maassen 2006). In his best-seller Engines of Creation (1986) Eric Drexler claimed to replace the conventional top-down design methods (such as microlithography for instance) developed in the miniaturization of computer technologies by bottom-up methods with "molecular assemblers" that would pick and place individual molecules to assemble them in functional modules or molecular machines. Drexler's perspective of a molecular manufacture inspired by Lego sets raised sarcasms from chemists. In particular, Richard Smalley (2001) argued that at the nanometre scale atoms are all interconnected and sensitive to the placement of other atoms in the vicinity. The only way to deal with this 'intricate dance of atoms' is to let them self-assemble.

To sum-up, unlike self-organization self-assembly became a booming field of research in an engineering context as a technique for making artefacts bottom-up at the molecular level. In their exploration of the potentials of molecular self-assembly chemists and materials scientists certainly came closer to biologists but most of them were not interested in addressing the issue of emergence or reducing the complexity life to physics or chemistry. On the contrary Whitesides (2004) claimed that chemistry so far blindly reductionist was becoming complex because of its investigation of biological phenomena.

\section{Where does the "genius" lie?}


There is no self-assembly without the assumption of a spontaneous activity of matter, an intrinsic dunamis that can be observed at the molecular level. It enables atoms and molecules to construct a variety of geometrical shapes: helix, spiral, hollow sphere, ellipsoid, tube..... Smalley, who was awarded the Nobel Prize for his contribution to the discovery of fullerenes, elegantly referred to the 'genius' of carbon:

The discovery that garnered the Nobel Prize was the realization that the carbon makes the truncated icosahedral molecule, and larger geodesic cages, all by itself. Carbon has wired within it, as part of its birthright ever since the beginning of this universe, the genius for spontaneously assembling into fullerenes (Smalley 1996).

What can be the "genius" of a chemical element like carbon? It is certainly not an obscure and mysterious vital force, a kind of animus that would come from the outside and infuse life into inanimate matter. The term "genius" referring to a natural ability and at the same time connoting an ingenuous, skilful invention definitely blurs the boundary between the natural and the artificial, between what results from a material process and what is man-made.

It challenges the Kantian theory of objective knowledge, which relies on a dichotomy between nature, defined by the stability of structures and operations that connote instability, becoming and process. For Kant, only living beings challenge the divide between structure and operation because they are self-organized. Therefore there is no objective knowledge of living organisms, which are dealt with in the Critique of Judgement rather than in the Critique of Pure Reason. According to French philosopher Gilbert Simondon (1952) Kant's dichotomy between structure and operation also implied that technology is a kind of corruption of nature, a denaturation (Guchet 2009).

Blurring the boundary between the grand divides that organize our modern culture - such as nature/artefact, nature/culture, or humans/non humans - has become a commonplace in the current post-modernist literature since Bruno Latour's famous essay We Have Never Been Modern (1993). Not only the entanglement of matter and humans is a major feature of postmodernism but American feminist theorist Karen Barad promoted the performativity of matter as an icon of a feminist metaphysics labelled "agential realism" (Barad 2003).

However there is no need of any commitment to postmodernist or posthumanist discourses to realize that nanotechnologists no longer consider matter as a static and passive entity awaiting information from scientists and designers. In granting "genius" and performativity to molecules, in using their performances to make smart artefacts, materials chemists and nanoscientists give up the Cartesian view of nature and create a new metaphysical landscape.

Nature is no longer viewed as a static given: the natura naturata gives way to a natura naturans, a continuous process of formation (Bensaude Vincent 2009, Nordmann 2010, Bensaude Vincent et al. 2011). Kant's clear metaphysical divide between nature's immutable structures and operations, which delineated the boundary between the domains of objective science and technological action, becomes obsolete. Technosciences such as nanotechnology 
and biotechnology invite us to assume Simondon's claim that operativity is an objective natural phenomenon (Guchet 2009).

Although technoscientists never openly discuss ontological questions they all recruit material agencies to enhance the potentials of nature. However they differ about what kind of agency is embedded in matter and at what level. Where does the "genius" lie in matter and how does it operate? It is possible to delineate at least two radically different views in current practices of self-assembly.

Genetic engineering and synthetic biology rely on the assumption that the agency of matter lies in the genetic code. Accordingly, one major objective is to modify the code, or to rewrite it. Genome-driven cell engineering is one of the methods developed in synthetic biology. It consists in the modification or the synthesis of a whole genome which is transplanted into cells with a view to reprogram them. This strategy is instantiated in Craig Venter's team successful synthesis of Mycoplasma Laboratorium in 2010. Reprogramming the machinery of a cell is supposed to be sufficient to change and control its performances because the genome is viewed as the causal engine of the cell. In their effort to "redesign life" synthetic biologists revive the standard hylomorphic model since the complex behaviour of a cell results from the information of matter, or the imposition of a plan on a substrate. Indeed the instructions that command the structure and behaviour lie within the molecules of DNA and RNA, they are no longer impressed from the outside. However the metaphor of the program suggests a clear distinction and independence of the software (the genetic code) from the hardware (the molecular machinery of the cell). The genome is analogous to a designer informing matter and controlling its behaviour. As anthropologists Tim Ingold notices the genetic code is reminiscent of the clockmaker argument developed by natural theologians. "The attribution of ultimate responsibility for the design to natural selection rather than God does not affect the logic of the argument, namely that there can be no functional complexity without prior design" (Ingold 2013: 67). The agentivity of matter is located in the central instructions encoded in DNA.

By contrast, in biomimetic approaches there is no identifiable set of instructions acting as a designer. The organization and performances of molecules result from the interactions between molecules and with their environment. Although modern chemists share with biologists the conviction that living organisms are controlled by the DNA-RNA system, which contains the instructions for the machine to operate, they do not try to access and modify the code. Their challenge is to dispense with the information of the genetic code in order to self-assemble the components and to control morphogenesis. For this purpose, they play with intermolecular bonds rather than making and breaking covalent bonds between atoms as organic chemists used to do. They use reversible reactions and let molecules explore the range of possible combinations. They are looking for what interactions of molecules can afford while they resort on tricks to obtain complex systems. All the resources of physics and chemistry are put at work: chemical transformations in spatially restricted reaction fields, external solicitations like gravity, electric or magnetic fields, mechanical stress, gradients and flux of reagents during the synthesis. 
Biomimetic processes are based on a combination of affordances and contrivances. The resources displayed by the interrelations and interactions between molecular entities interplay with astute tricks to monitor the spontaneous dynamics of molecules. When a substrate binds to an enzyme or a drug to its target, when signals propagate between cells, highly selective interactions occur between the partners and control the process. Supramolecular chemists investigate and implement these interactions in specially designed non-natural systems. They deal with populations of molecules and take advantage of their selectivity, their ability to recognize each other, their tendency to assemble or separate themselves. In other terms, the biomimetic approach is based on a morphogenetic model, where complex functional structures result from the collective behaviour of molecules. An order emerges out of the confluence of atoms or molecules. In order to stress that something emerges from the molecules 'being together', Lehn often claims that a glass full of water is different from a single water molecule because isolated molecules do not behave like interacting ones. The collective behaviour results from coupling processes rather than being just the expression of the information contained in each individual component. Lehn's program of Constitutional Dynamical Chemistry is a sort of molecular sociology relying on the group dynamics of an ensemble of individuals and their interactions with the milieu.

Because in biomimetic practices molecules are viewed as relational and dynamic entities, they are better defined as affordances rather than as agencies. The concept of affordance revisited by Rom Harré (2003) refers to both the dispositions of atoms and the world/apparatus complex. It is a hybrid of nature and artefact, of objective properties and human purposes.

\section{A design without designer}

We have seen that the biomimetic approach developed by chemists presupposes that intrinsic contrivances in chemical molecules generate spontaneous order, whereas the synthetic biology approach relies on the assumption that the order is generated by central instructions embedded in the genome. As they still assume that a master plan is responsible for the performances of a cell, synthetic biologists are entitled to use the phrase "designing" or "redesigning life" and to present themselves as rational designers. In the Biobricks agenda, which dominates synthetic biology, their practice of is based on the model of scientific reason, which prescribes to proceed from the simple to the complex aim is to assemble bricks like Lego blocks into modules that will be in turn assembled into systems.

By contrast self-assembly is a blind process of interactions through combinations and selection without rational designer. Although chemists occasionally use such phrases as "selforganization by design" (Lehn 2004) or "we self-assemble molecules", the process is going on without human involvement. The subject "we" just initiates the process of self-assembly by securing the necessary agencies and appropriate conditions.

The attractive power of self-assembly techniques is precisely that they open the way to a design without designer and more broadly to machines working without humans as 
Whitesides emphasizes:

A self assembling process is one in which humans are not actively involved, in which atoms, molecules, aggregates of molecules and components arrange themselves into ordered, functioning entities without human intervention... People may design the process, and they may launch it, but once under way it proceeds according to its own internal plan, either toward an energetically stable form or toward some system whose form and function are encoded in its parts (Whitesides 1995).

Self-assembly opens the fascinating perspective of a world of self-made machines capable of regulating their operation rather than working on the basis of a program. Such machines are not necessarily confined to the biological realm or to biomimetic processes. The archetype of self-operating devices could be the gnomon - the stick or the tree, which shows the time by the position of its shadow (Serres 1989). This prototype of a sundial is both natural and technological. There is no need of a thinking subject to design it. Similarly self-asssembly is not a "human fabrication " in the sense that the assembly process is not operated by human hands or tools. In this respect, self-operating machines are different from a robot performing human tasks because the robot has been programmed. Despite the frequency of bugs, the designer can feel that the machine is under control because the program is her creation.

What kind of control of the spontaneous process of self-assembly is involved in biomimetic strategies? Biomimetic chemists are inducing a process that delegates the task of building up to a "society" of interacting molecules. They delegate the operations they want to perform to molecules, radicals, ions..., which are not their own creation. The result of their design is not entirely the product of their hands and brain. It is mainly the offspring of a spontaneous process. In this respect, chemist and material scientists who design self-assembled structures do not have the same responsibility as the clockmaker.

Does it mean that self-assembly could work without humans? Simondon claimed that selfregulating machines such as cybernetic machines, do not dispense with human interventions. Rather they change the nature of human intervention: while conventional machines depend on humans as designers and organizers, self-regulating machines require humans as technicians, i.e. as "associates" (Simondon 1958: 174). Similarly, biomimetic chemists are the associates of nature or pilots of spontaneous material processes. Pilots rely both on natural elements and instruments to guide their sea boat. They work with nature. More precisely they negotiate with nature rather than imposing their norms and standards on nature. They know that all journeys are risky, that the success of their enterprise involves a good deal of uncertainties.

\section{Conclusion}

Material scientists and engineers who develop biomimetic practices of self-assembly do not try to reproduce life. Unlike nineteenth-century chemists they take inspiration from the processes of synthesis developed during the course of the evolution of life on earth for developing their own 'biomimetic' synthetic strategies. It is no longer a question of proving 
that life can be reduced to the interplay of chemical forces view a view to defeat claims that life is something essentially different from inanimate nature. The goal is to and design smart devices from bottom-up, from atoms and molecules to machines and systems.

If the old debate vitalism versus mechanicism has lost salience, it is not because technosciences such as nanotechnology or biotechnology would be ontology-free. Rather it is because an alternative ontology is underlying the practices of making from bottom up. In this ontology material entities are essentially active. The view that agency is essential to matter is by no means novel. It can be seen as the continuation of a century-long tradition opposed to the Cartesian view of nature as passive matter and developed by Diderot or La Mettrie (Riskin 2015). In this materialistic perspective there is no need of a divine clockmaker since material entities are endowed with an intrinsic power to self-assemble into more complex structures.

However there are two different ways of naturalizing the divine designer. Either the designer is embodied in specific molecules such as DNA and RNA that contain the instructions for other molecules to operate. Or the designer gives way to a process of design that is performed by a crowd of interacting molecules co-operating with their environment, albeit triggered by humans. In the former case, the agency of matter is concentrated in a code or program informing matter. In the latter case, the material arrangement of molecules affords performances. In both cases, the practices of self-assembly are based on strict materialistic assumptions. But chemistry reconfigured by biomimetic practices is much less reductionist than biology reconfigured by technological ambitions.

\section{References}

Atlan, H. (1972) L'organisation biologique et la théorie de l'information. Paris: Hermann. Atlan, H. (1979) Entre le cristal et la fumée, Paris: Seuil-Point science.

Ball, P. (2002) Natural strategies for the molecular engineer, Nanotechnology, 13, 15-28.

Barad K. (2003), Posthumanist performativity : toward an understanding of how matter comes to matter, Signs, 28 (3), 801-831.

Bensaude Vincent B. (2009) Les Vertiges de la technoscience. Façonner le monde atome par atome. Paris:La Découverte.

Bensaude Vincent B., Simon J. (2008) Chemistry, the Impure Science, London: Imperial College Press.

Bensaude Vincent B, Loeve S. Nordmann A., Schwarz A (2011) Matters of Interest: The Objects of Research in Science and Technoscience, Journal for General Philosophy of

Science, 42 (2), 365-383.

Bernard, C. (1865) Introduction à l'étude de la méthode expérimentale en médecine, Paris: Flammarion, 1984.

Bernard, C. (1878) Leçons sur les phénomènes de la vie communs aux animaux et aux végétaux, Paris: Vrin, 1966.

Berthelot, M. (1860), La chimie organique fondée sur la synthèse, Alcan, Paris.

Brooke, J. H. (1968) Wöhler's Urea and its Vital Force - A Verdict from the Chemists, Ambix, $15,84-114$.

Dujardin, E. \& Mann (2002) S. Bio-inspired materials chemistry. Advanced Materials, 14, 775-788. 
Feltz B., Crommelinck M., Goujon P. (2006) Self-Organization and Emergence in Life Sciences. Dordrecht: Springer.

Guchet X. (2009) "Nature and artefact in nanotechnology", Hyle, 15 (1), 5-14.

Harré R. (2003) The materiality of instruments in a metaphysics for experiments, in H.

Radder (Ed.) The philosophy of Experimentation (pp.19-38) Pittsburgh: Pittsburgh University Press.

Ingold T. (2013) Making Anthropology, Archeology, Art and Architecture, London:

Routledge.

Latour B. (1993) We Have Never Been Modern, Cambridge Mass.: Harvard University Press. Lehn J.M. (2003) , “Une chimie supramoléculaire foisonnante," La lettre de l'Académie des sciences 10, 12-13.

Maasen S. (2006) "The assembled self of nanotechnology: The career of self-assembly as a metaphor", paper presented at EASST Conference, Lausanne.

Mann S., Werbb J., and Williams R. eds. (1989) Biomineralization, Chemical and Biological Perspectives, Weinheim, VCH.

Nicolis, G. and Prigogine, I. (1977). Self-organization in nonequilibrium systems: From dissipative structures to order through fluctuations. Wiley: New York.

Nordmann A. (2010) Enhancing Material Nature in Kamilla Lein Kjølberg and Fern Wickson (Eds.) Nano meets Macro: Social Perspectives on Nanoscale Sciences and Technologies (pp. 283-306), Singapur: Panstanford.

O’Malley M. (2007) Knowledge making distinctions in synthetic biology, BioEssays, 30, 5765.

Prigogine, I. and Stengers, I. (1984) Order out of chaos: Man's new dialogue with nature.

New York: Bantam Books.

Ramberg P. (2000) The Death of Vitalism and the Birth of Organic Chemistry: Wölher's Urea Synthesis and the Disciplinary Identity of Chemistry, Ambix, 47, 170-195.

Riskin J. (2015) The Restless Clock. A history of century-long argument over what make living things tick, Chicago : The University of Chicago Press.

Sanchez C., Arribart H., and Giraud-Guille M. (2005) Biomimetism and bioinspiration as tools for the design of innovative materials systems, Nature Materials. 4, 277-288.

Serres M. (1989), Gnomon, les débuts de la géométrie grecque, in M. Serres (Ed) Eléments d'histoire des sciences (pp. 63-99), Paris: Bordas.

Simondon G (1952) Epistémologie de la cybernétique, unpublished paper.

Simondon G (1958), Du mode d'existence des objets techniques, Paris, Aubier-Montaigne $2^{\text {nd }}$ ed. 1989.

Smalley, R.E. (1996) Discovering the Fullerenes, Nobel Lecture December 7, 1996, http://cnrst.rice.edu.

Smalley, R. E. (2001). Of chemistry, love and nanobots, Scientific American, 285 (3), 76-7. Stengers Isabelle (1985) Les généalogies de l'auto-organisation, Cahiers du CREA, 8, 7-104. Von Foerster, H. (1960) On self-organizing systems and their environments in M.C. Yovits and S. Cameron (Eds.), Self-organizing systems (pp. 31-50) London: Pergamon Press. http://e1020.pbworks.com/f/fulltext.pdf

Whitesides G. (1995), Self-Assembling Materials, Scientific American, 146-9. https://gmwgroup.harvard.edu/pubs/pdf/431.pdf 